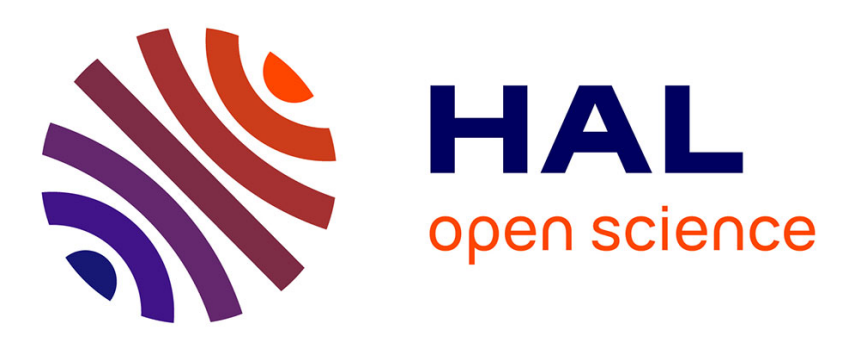

\title{
The US Automobile Market after the "Great Recession": Back to Business as Usual or Birth of a New Industry?
}

Bruno Jetin

\section{To cite this version:}

Bruno Jetin. The US Automobile Market after the "Great Recession": Back to Business as Usual or Birth of a New Industry?. Bruno Jetin. Global Automobile Demand. Vol.1: Major Trends in Mature Economies, Palgrave/McMillan, pp.10-36, 2015. halshs-03216764

\section{HAL Id: halshs-03216764 https://shs.hal.science/halshs-03216764}

Submitted on 5 May 2021

HAL is a multi-disciplinary open access archive for the deposit and dissemination of scientific research documents, whether they are published or not. The documents may come from teaching and research institutions in France or abroad, or from public or private research centers.
L'archive ouverte pluridisciplinaire HAL, est destinée au dépôt et à la diffusion de documents scientifiques de niveau recherche, publiés ou non, émanant des établissements d'enseignement et de recherche français ou étrangers, des laboratoires publics ou privés. 
Citation: B. Jetin (2015). "The US Automobile Market Before and After the "Great Recession": Back to Business as Usual or Birth of a New Industry? In B. Jetin (editor): « Global Automobile Demand. Vol.1: Major Trends in Mature Economies". Palgrave McMillan, Basingstoke and New York.

\section{The US automobile market after the "great recession": back to business as usual or birth of a new industry?}

\section{Bruno Jetin.}

\section{Introduction}

Between December 2007 and June 2009, the US economy was hit by the "great recession", the worst since the "Great Depression" of the thirties. As a consequence, the US automobile industry has gone through a crisis of unrivalled magnitude: during the recession, light-vehicles sales lost 6 million units and two of the "big three", GM and Chrysler went bankrupt. Since then, the US economy has recovered progressively and the automobile market is bouncing back to its pre-recession level. In fact, the automobile industry has better recovered than the rest of the economy whose growth is weak and uncertain. GM and Chrysler emerged from bankruptcy as new slimmed-down companies with fewer brands, plants, workers, less debt and market share. The rejuvenated "big three" returned to profit in 2009 (Ford) or 2010 (GM and Chrysler) when the US market was still below 12 million vehicles sales a year. They are making bigger profit now that the market is expanding again and on the way to reach the 16 million units in a near future. GM and Chrysler have repaid their loans and have gone public again, a move that has given the US federal state a way to sell part of its stake in the companies' stock.

These events may suggest that the crisis is over and that the US automobile industry is back to the usual pattern that prevailed before the "great recession". This chapter will show that there is more than meets the eye. There are short-term factors that are indeed acting positively for the automobile market. But at the medium to long-term the structural problems that have led the US economy to the crisis have not been resolved and will weigh heavily again. First, the US economy is recovering slowly and unemployment stays at a high level contrary to previous recessions. A new jobless recovery seems under way as after the dotcom bubble burst in 2001. Family income has dropped, poverty has risen and inequality has worsened. Second, structural factors such as the slower growth of the number of licensed drivers and a change in consumer expenditures due to growing costs of education, health and accommodation is affecting negatively car demand. In this context, the rebound of the automobile market is no doubt fragile. The temptation is strong to go back to the traditional recipes of household' indebtedness to stimulate car demand. Banks, 
captive finance automobile companies and independent finance companies have loosened their credit standards and are originating loans actively. The subprime automobile credit market is back thanks to the reviving of asset-backed securities market that played such a critical role in the build-up of the "great recession". The danger is the return of the dependency of the automobile market on bad loans to increase sales.

This chapter will analyse these contradictory tendencies. The first part is comes back to the analysis of the Great Recession to see how much it was the consequence of an unsustainable growth regime whereby a decreasing labour income share coupled with growing social inequalities have led US households to take even more debt to maintain their consumption pattern. This growth regime has modelled car demand and car financing in a way that parallels the housing market. In a second part, we analyse the rebound of the automobile market to see why there are many reasons to think that it will be short-lived. The fundamental reason is that the US growth regime has not changed. Other important reasons are more structural: the changing demographics, consumption pattern, of gas price, and the absence of breakthrough innovation in alternative fuel cars likely to reduce dramatically the cost of motoring when it is most needed.

\section{A debt-driven growth regime paved the way to the Great Recession.}

The automobile industry usually follows the fluctuations of growth cycles. In the USA new vehicle sales have been especially buoyant during the growth cycles 1961$1969,1982-1990$ and most particularly in the cycle of the so-called "new economy" 1992-2000 (see Figure 1). 


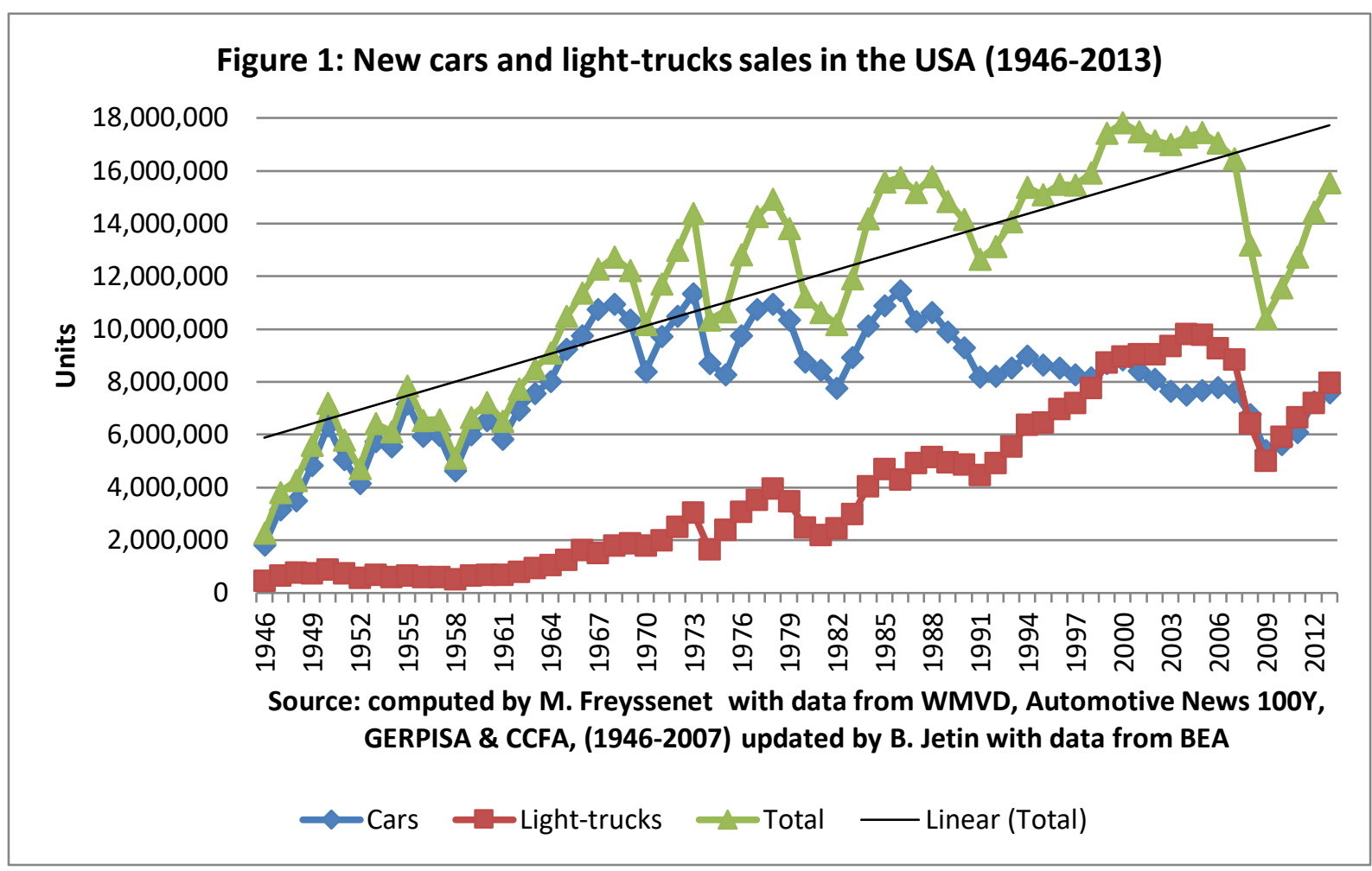

The "feeble recovery" of 2001-2007 (Bivens and John 2008) which followed the dot.com bubble burst (March 2000- June 2003) broke down the rule ${ }^{1}$. The Gross Domestic Product (GDP) and employment growth were at the time the weakest since 1949, but new vehicle sales stayed at a high level, above 16 million units (see Figure 1). Sport and Utility vehicles (SUV) sales topped at almost 10 million units while they are usually more expensive than passenger cars. With 17.4 million units in 2005, vehicle sales were not far from the historical record of 17.8 million of 2000 , when the so-called "new economy" reached its apex. There was obviously something wrong in the boom of the automobile market during the growth cycle 2001-2007 that cannot only be explained by the fall of the interest rate to zero after the September 11, 2001 attacks which revived the economy. Nor can the fall of the automobile market be explained by the Great Recession triggered by the "subprime crisis". The Great Recession officially begun in December 2007 and ended in June 2009 but vehicle sales had started to decrease in 2005.

The origin of this disconnection is to be found in the structural changes of the US growth pattern introduced by supply-side economics launched by Ronald Reagan in

\footnotetext{
${ }^{1}$ According to the National Bureau of Economic Research (NBER), the US economy was in recession from March 2001 to November 2001. The precise dating has been much debated because there were no two consecutive negative quarters and growth remained weak until the first quarter of 2003. The end of the dotcom burst can be dated to June 2003 when the NASDAQ index started a new upward trend. Bivens and Irons (2008) qualify the growth cycle $2001-2007$ as "feeble" because "it was a full $40 \%$ slower than the post-World War II average (2.7\% versus $4.8 \%$ in previous expansions)".
} 
1980. Since then, the percentage gap between labour productivity and real compensation has widened (see Figure 2).

The gap was closed to zero between 1947 and 1973 (0.2\%). It almost doubled in the eighties $(0.8 \%)$ compared to the seventies $(0.5 \%)$. It narrowed a little bit during the growth cycle of the nineties $(0.7 \%)$. But during the "feeble recovery" of the years 2001-2007 it more than double again (1.6\%) and after the Great Recession the gap stayed at the same level. On the long term, this means that real compensation of American households did not benefit as much as they could. In particular since the Great Recession, real compensation remained flat while companies were profiting much more from productivity gains. Besides, the income distribution got more and more unequal. "Data on income concentration going back to 1913 show that the top $1 \%$ of wage earners now hold $23 \%$ of total income, the highest inequality level in any year on record, bar one: 1928.

In the last few years alone, $\$ 400$ billion of pre-tax income flowed from the bottom $95 \%$ of earners to the top $5 \%$, a loss of $\$ 3,660$ per household on average in the bottom 95\%" (Lawrence et al. 2008). This phenomenon has not affected immediately households' consumption for two reasons.

Figure 2:Labour productivity and real compensation gap in the USA, 1947-2013

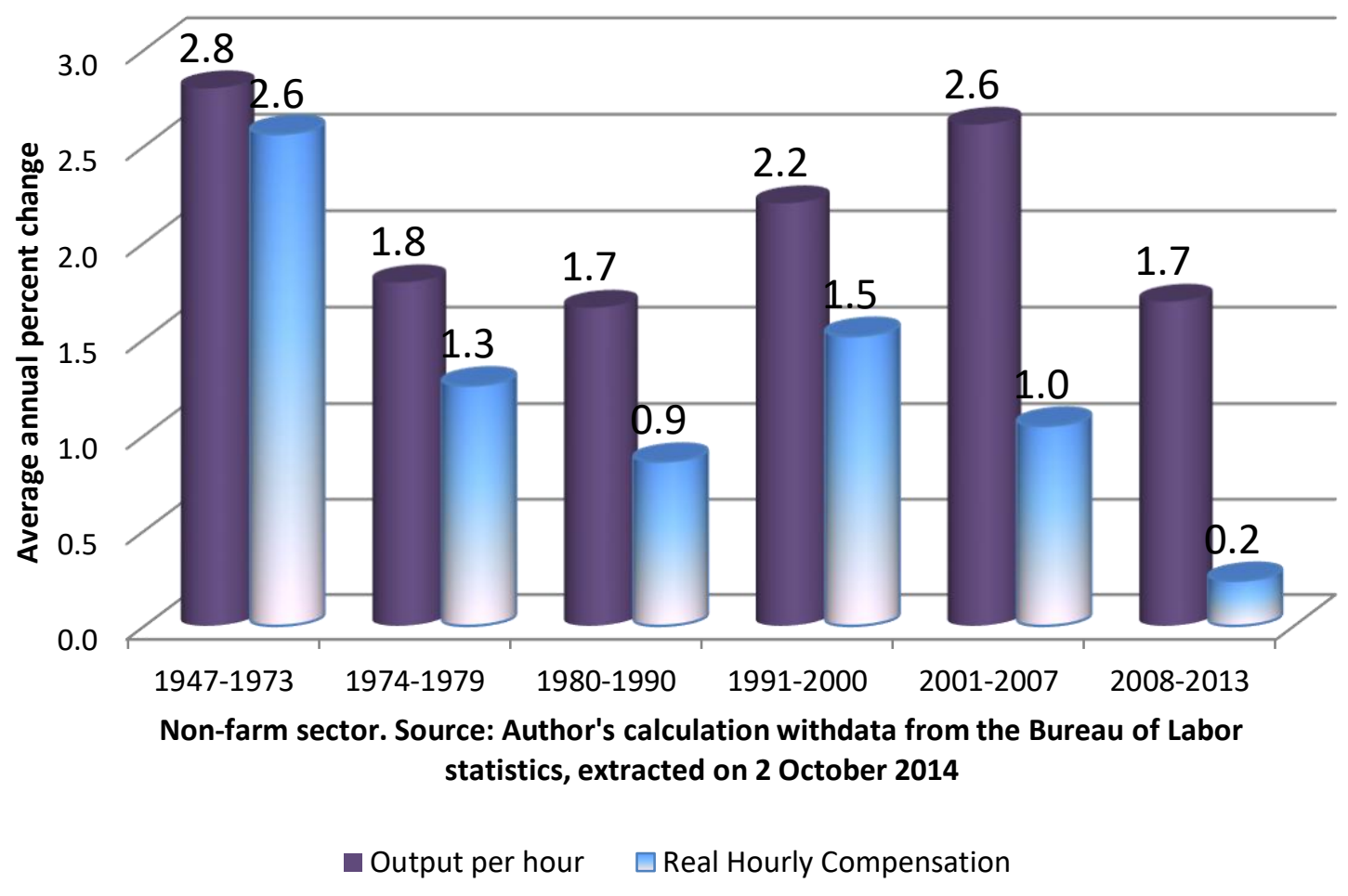


First, households have swap income increase with debt increase to maintain their standards of living and acquire their home. This was made possible by the strong support of the State and the adoption of various laws by Congress. The standardisation of mortgages and the introduction of mortgage-backed securities took shape in the 1960s. Later a decisive step was taken with the Tax Reform Act of 1986 which phased out the deductibility of most non-mortgage interest for instance interest on consumer loans. "This led to a shift of consumer debt towards mortgages and home equity lines" (Stango 1999). Homeownership became the foundation of a stable middle class and house mortgages became the cornerstone of household debt $^{2}$. As a consequence, household debt as a percentage of disposal income which was stable around $60 \%$ since 1965 started to grow rapidly to almost $100 \%$ in 2000 at the end of the "new economy" bubble growth (see Figure 3).

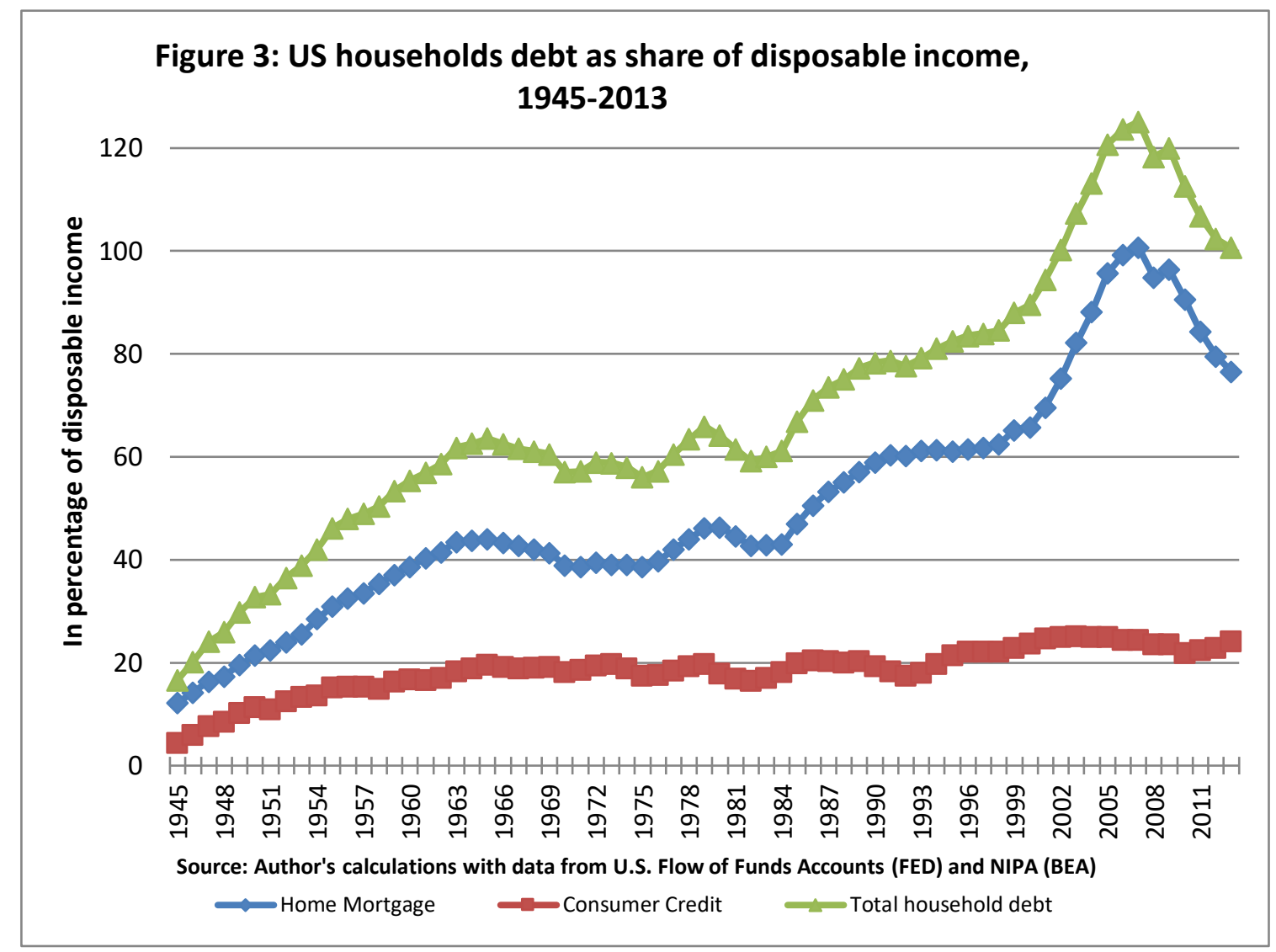

The bursting of the dot.com bubble burst in 2000-01 had the well-known effect to shift the focus of speculation from shares to housing. A new wave of finance was investing in house construction and in home mortgage and house prices soared. Despite the "jobless recovery" that succeeded (2001-2007), indebtedness skyrocketed to more than $120 \%$ in 2007.

\footnotetext{
2 The Homeownership rate which stayed flat around $64 \%$ during the seventies and eighties increased steadily in the nineties and hit a peak in 2004 at $69 \%$ and plateaued at that level until the Great Recession. In 2013, it was down to 65\%, a level first reached in 1978. Source: US Census.
} 
As a consequence, with the exception of recession periods, consumption has constantly increased at a higher pace than compensation. Increasing debts filled the gap to the point that one can call the US growth regime at the time "a debt-driven growth regime". Three special features of financial innovation in a context of low interest rates and rising house prices explain why debt did not only finance ordinary consumption but created a consumption boom. In sum, these innovations contributes to explain why during the feeble recovery preceding the Great Recession, vehicles sales boomed and averaged 17.2 million units above the 16 million landmarks achieved in the eighties and nineties.

First the upward trend in house price generated a house wealth effect much more significant than the stock market wealth effect ${ }^{3}$. An enormous wave of refinancing of existing mortgages, during the years 2000-2006 allowed homeowners to extract some of the built-up equity in their homes. Part was used to pay down more expensive non-tax deductible consumer debt or used to make purchase that would otherwise have been financed by more expensive and less tax-favoured credit. In this sense, the refinancing phenomenon has been a supportive factor for growth as long as homeowners were able to pay their monthly payments. Daniel Cooper (2010) shows that "during the height of the house-priced boom (the years 2003-2005), a one-dollar increase in equity extraction led to 14 cents higher household expenditures". Overall, the increase was broadly concentrated in transportationrelated expenses, food schooling, and non-major home upkeep.

There is a positive and strong relationship between equity extraction and automobile costs which include down payment for loans and leases. There is also a smaller positive effect of equity extraction and health care costs, which is consistent with the idea that households used equity extraction to help funding big-ticket expenditures. The problem with this financial extraction is that when house prices began to decline in 2006, it contributed to higher defaults. According to Mian and Sufi (2009), it accounted to 34\% of new defaults from 2006 to 2008. In another paper, the same authors show that the rise of households' debt-to-income ratio and the growing dependence on credit card borrowing during the years before the recession explain a large fraction of the crisis and its effect on durable consumption. In particular, they show that "counties that experienced the largest increase in their debt-to-income ratio from 2002 to 2006, saw a severe contraction in auto sales very early in the downturn" and a higher increase in unemployment (Mian and Sufi 2010: 95). By contrast, in lowleveraged counties, auto sales were up in the first quarter of 2008 and dropped only in the third quarter of 2008 when the crisis affected the whole country.

\footnotetext{
${ }^{3}$ Greenspan and Kennedy (2007) shows that during the housing boom market of 2001-2005, an average of just under $\$ 700$ billion of equity was extracted each year by home equity loans, cash-out refinance, and second mortgages. Case, Quigley and Shiller (2013) argue that over the same period, the housing wealth effect pushed up households spending by $4.3 \%$, a much stronger effect than the financial wealth effect.
} 
Second, financial innovations combined with the house price boom allowed households to take more debt secured on the value of their house. A secure loan is a loan for which the lender receives collateral in return. Mortgages and car loans are among the most common secured loans. In these cases, collateral is provided to the lending institution in the form of a lien on the title to the property until the loan is paid off in full. If the borrower defaults on the loan, the lender retains the right to repossess the property (Ruben 2009). Low interest rates, appreciation in house value and the deductibility of interest payments on mortgage-debt have induced households to borrow against the equity in their home. This process depended crucially on the assumption that continuous rising house values outpace the increase in home-secured debt.

Third, financial innovations also developed the so-called sub-prime market and Adjustable -Rate Mortgage (ARM) to low-income consumers not traditionally served by the mortgage market. Sub-prime loans have interest rates that are higher than standard prime mortgages as a direct result of the greater risk associated with holding the debt. ARM offered lenders the opportunity to put off big payments until later, seducing borrowers with lower initial payments and low initial interest rates. Due to relaxed underwriting criteria, subprime loans and ARM were sold to consumers who were unlikely to be able to repay the loan should interest rates rise. Borrowing became much easier, thanks to the conventional belief that the growing value of the house would provide adequate collateral.

This belief was brutally refuted in 2007 when house price began to drop. A growing number of households were caught in into a debt trap. Homeowners' financial obligations soared from $13.8 \%$ in 1980 to $17.7 \%$ in 2007 . Households' financial delinquency ${ }^{4}$ on single family residential mortgage which was on average $2 \%$ during the nineties skyrocketed $11.3 \%$ in the first quarter of 2010 . Financial delinquency on credit cards topped at $6.5 \%$ in 2009 and delinquency on student loans is also rising. Personal bankruptcy filings as a share of households was multiplied by 4.5 between 1980 and 2005 when it reached a record level before a new law made it harder and more expensive to petition for bankruptcy.

The effect of the crisis on the automobile market was dramatic. Auto delinquency loans increased to high level and stayed high level long after the official end of the recession (Figure 4). Only in the fourth quarter of 2014 had the 60 days delinquency rate returned to the level of 2006 while the 30 days delinquency rate was still above it. These Figures may look small in percentage point, but the dollar amount is quite important. In the first quarter of 2010 Automotive loans that were 30- or 60-days delinquent amounted to nearly $\$ 20$ billion. It dropped to $\$ 16$ billion in Q1 2011 signalling an improvement as households try to pay their debt.

\footnotetext{
${ }^{4}$ Delinquent loans mortgage and leases are those past due thirty days or more and still accruing interest as well as those in nonaccrual status. They are measured as a percentage of the end-of-period. Source, FED.
} 
What we call the "debt-driven growth regime" was not sustainable. The decline in house prices triggered the so-called "subprime crisis" which ended with the "Great Recession". American households have entered in a painful phase of deleveraging. By 2013, most of financial distress indicators had declined and returned to level close or below pre-recession levels except those related with residential mortgages.

The automobile market has also recovered. In 2013 sales of new cars and light trucks have reached 15.5 million units up from 10.4 million in 2009 in the height of the "Great Recession" 5 (see Figure 1). The V-shaped recovery has sparked a wave of optimism in the automobile industry and confidence in the possibility to reach in the coming years the previous sales record of almost 18 million units of the year 2000 . Does it mean that the crisis is over and that the automobile demand is now set on solid basis?

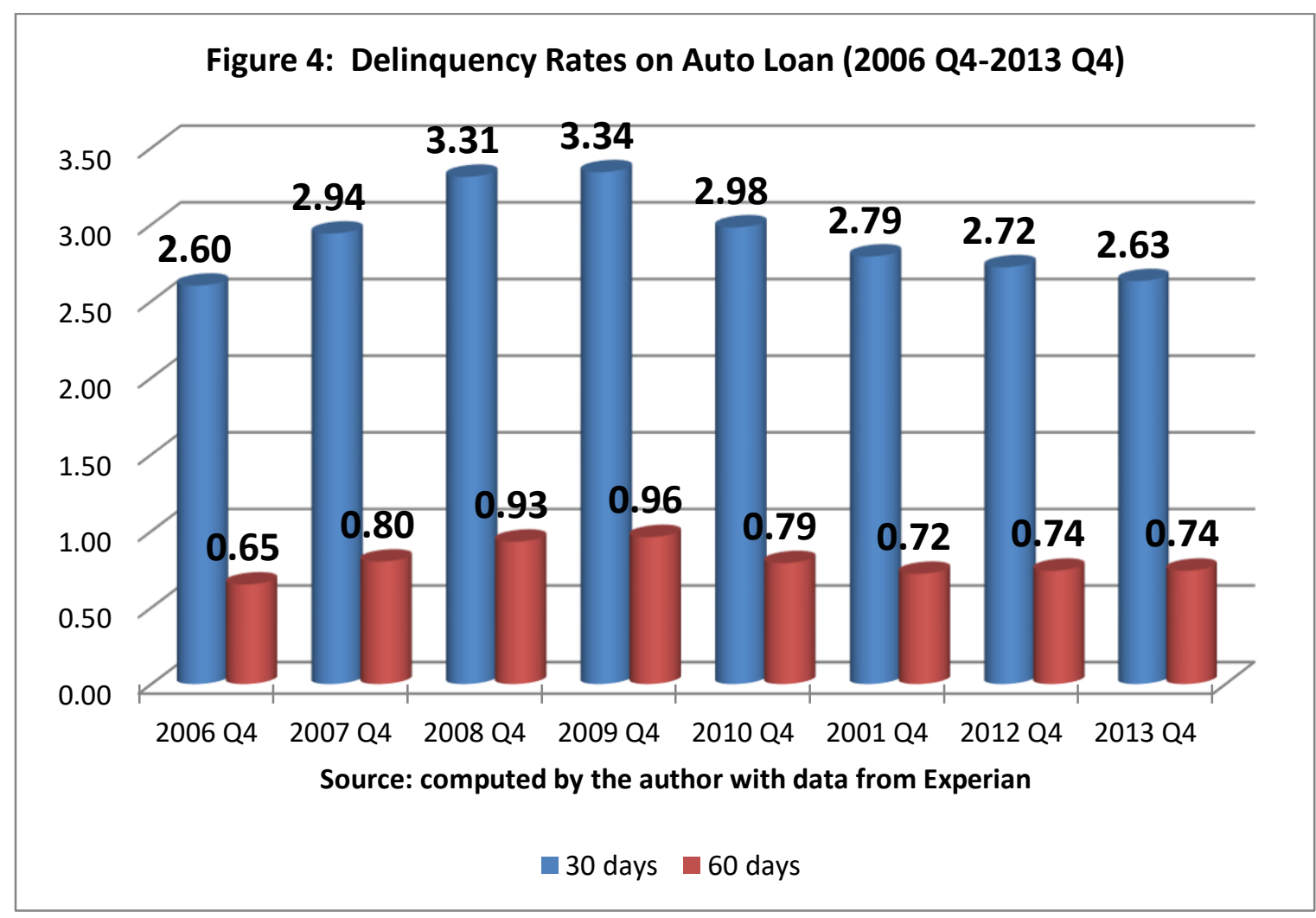

\section{The US automobile market has recovered thanks to exceptional cyclical factors.}

The optimism is based on several favourable factors that have helped the auto market bouncing from the trough: job creation, the end of households' deleveraging

${ }^{5}$ According to the NBER, the "Great Recession" officially began in December 2007 and ended in June 2009. 
process, aging of vehicles and pent-up demand, the quantitative monetary easing and its positive impact on automobile financing.

Employment is the major factor that determines the dynamism of the automobile market. In the first quarter of 2014, private employment with 116 millions of jobs exceeded for the first time the level it had in 2007 before the recession (115.7 millions). Total non-farm employment including public administration followed the same pattern. It means that more individuals were earning an income and were able to get a loan to buy a car. At the same time, having a car is usually the pre-condition to get a job.

Households were able to get financing to buy cars in sharp contrast with the credit crunch they experienced in 2008-2009. Households have cleaned their balance sheets and are now facing banks and financing companies willing to lend. Their debt now represents $104 \%$ of their disposable income down from $125 \%$ at the end of 2007. This is the result of six years of deleveraging which started in 2008 when households gave absolute priority to debt reduction and curbed their consumption. They borrowed less and paid down their existing liabilities with charge-offs also contributing to the decrease of aggregate balance. Mortgage, credit card and auto debts went through this deleveraging process with the exception of student loans. Students had no choice but to carry on with their loans to finish their studies. Student loans are now in crisis because new graduates can hardly find work. This weighs negatively on their capacity to consume and in particular to buy cars. But for the majority of households, the deleveraging ended recently in the third quarter of 2013 with an across-the-board growth in indebtedness ${ }^{6}$. This means that households are taking new loans to finance increasing expenditures. This is particularly the case of auto loans, which have started to expand since the last quarter of 2011, while other forms of debt were sill decreasing ${ }^{7}$. Since the free fall of the fourth quarter of 2008 ($26.8 \%$ ), motor vehicles and parts outlays, although highly unstable, have outperformed by far personal consumption expenditure during most of the recovery period. Consumption expenditures followed GDP growth and show no sign of acceleration which shows how fragile the recovery is. What explains this outperformance of automobile expenditures?

If we let aside the pick-up in the supply of auto loans enabled by the rehabilitation of banks and finance companies that will be analysed later on, two short-term factors explain the recovery of automobile demand: the aging of average households' vehicles and the release of pent-up demand. These two factors are intertwined. In 1995 the average car age was 8.4 years. It then rose steadily up to 10.4 years in

\footnotetext{
${ }^{6}$ Except for home equity lines of credit (HELOC) which are loans where the collateral is the borrower's house.

${ }^{7}$ Again, with the exception of student loans.
} 
2007, just before the recession. In 2011, after the recession, it had reached a historical peak of 11.1 years 8 . The share of vehicles by age shows that newer vehicles of less than five years dropped from $24 \%$ in 2002 down to $15 \%$ in 2012 while the share of vehicles 11 to 20 years old grew from $34.4 \%$ to $42.4 \%$ over the same timeframe (Pfirmann-Powell 2014). The continuous aging of light vehicles means that owners held on longer to their vehicles during the last recessions but did not reverse the pattern during recovery episodes. This is because these recoveries did not last long enough and income did not increase enough for households to absorb the financial loss of recessions and then purchase new vehicles in the magnitude necessary to lower the median age. This phenomenon was especially strong with the "Great Recession" and a high pent-up demand accumulated which is now underlying the V-shaped recovery of the automobile market. Customers have delayed their new car purchase for lack of financial means. In 2009 and 2010, many consumers and businesses scrapped cars without replacing all of them, despite the Car Allowance Rebate System ${ }^{9}$. These customers have shifted their demand to used vehicles pushing their prices up to historical levels ${ }^{10}$. As a consequence, new vehicles are relatively cheap compared to recent used vehicles. And low interest rates make them even more attractive. The convergence off all these factors explain why the release of pent-up demand is occurring now and has fuelled new vehicle sales since 2012 and probably for some years to come because older vehicles are just starting to being scrapped. But this positive factor cannot last forever.

The monetary policy known as "quantitative easing" has also played a strong role in the recovery of the automobile market. This unprecedented policy of money creation by the FED has pushed the interest rate to an all-time low level of almost zero percent in real terms. This policy has saved banks from bankruptcy and flushed them with all-time high amount of money that they try to lend with a profit in a context of low financial returns. Because vehicle purchase outperformed other consumer goods, banks and finance companies have started to lend in increasing amounts to car buyers at the start of 2012. Competition between banks, credit unions, captive auto finance companies, finance companies and auto retailers have pushed real interest rates below $2 \%$ for a 48 month-loan down from $8 \%$ on average in the eighties (see Figure 5), and extended loan maturity to over 60 months up from 35 months in 1971. This has expanded the auto market to financially constrained households

\footnotetext{
${ }^{8}$ For light trucks, the average age is slightly below: 8.3 years in 1995, 9 years in 2007 and 10.4 years in 2011. Source: Polk, reproduced by US Department of Energy, table 01.25, Transportation Energy data book, various editions.

9 This system known as the "Cash for Clunkers" program started in July 2009 and ended in August 2009. According to the US Department of Transport, the programme resulted in 690,114 transactions.

${ }^{10}$ The Manheim used car index (January $1995=100$ ) registered an all-time high of 124.9 in 2011 and is still at 121.4 on average in 2013.
} 
willing to purchase a new or used vehicle because the combination of low interest rate and long-term loans kept the average monthly payment stable ${ }^{11}$.

Banks were initially very conservative in their lending policy and focused on customer with best credit scores. But they have released gradually their standards from 2010 up to now. For instance, the share of consumers with Equifax credit score above $720^{12}$ peaked at over $52.4 \%$ in the fourth quarter of 2009 in the turmoil of the recession and is down to about $45 \%$ since the fourth quarter of 2012 . At the opposite, consumers with poor credit scores increased their share to $23 \%$ in the second quarter of 2013 up from $9.3 \%$ in the fourth quarter of 2009 . This is still well below the 25-30 \% shares registered before the "Great Recession" (Haughwout et al. 2013).

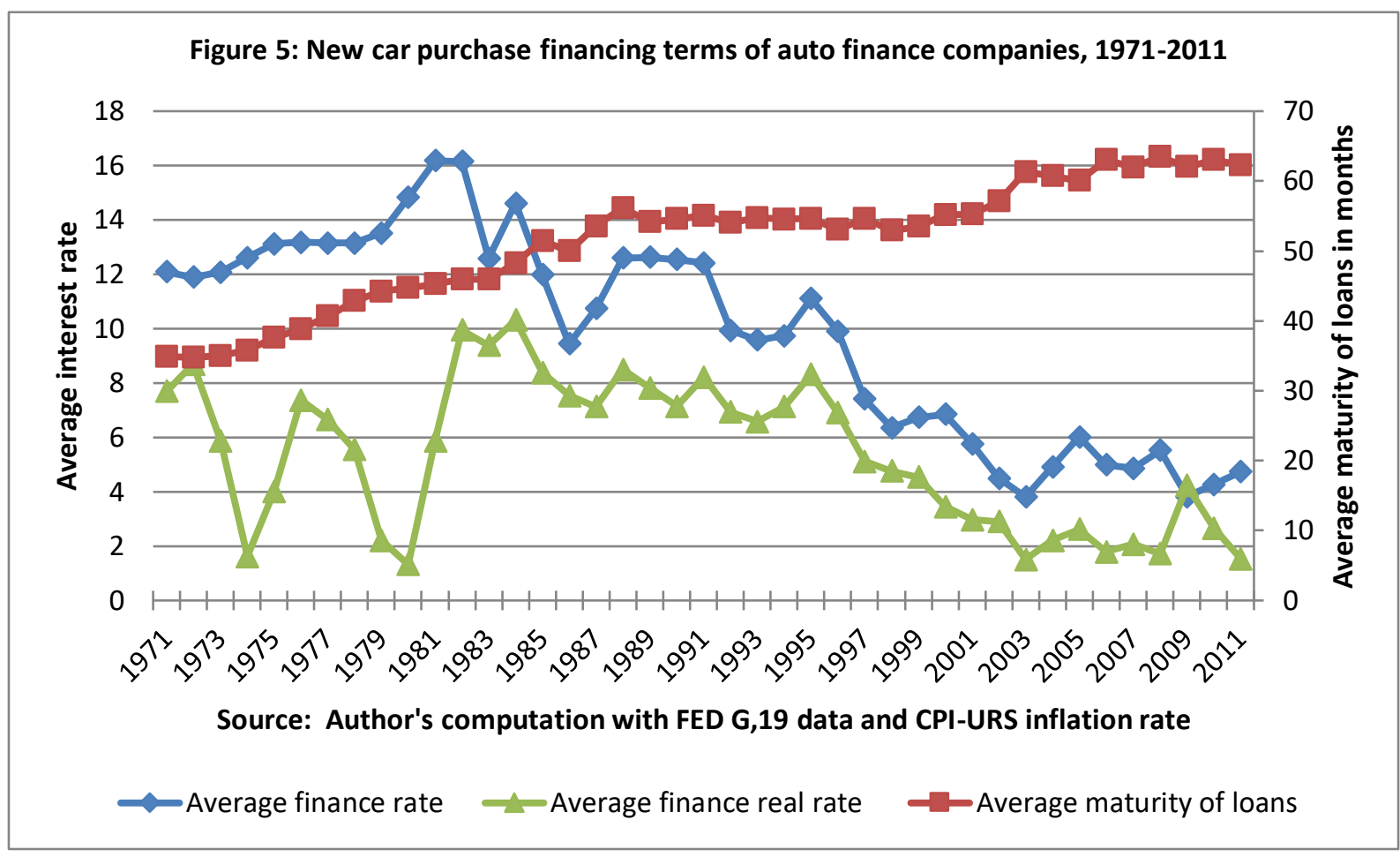

These favourable evolutions cannot improve continuously. One cannot expect an endless extension of loan term or another reduction of real interest rate to nearly zero percent with stable monthly payment. As we will see below, there is a limit to what finance can do and in particular the growing risk inherent to market extension to less

\footnotetext{
${ }^{11}$ For instance, the index of average amount financed for the purchase of a new vehicle increased $11 \%$ between the third quarter of 2008 and the third quarter of 2013 while the monthly payment increase by $2 \%$ only. Source: Author's calculations based on Experian data.

12 The Equifax Credit Score like the FICO Score are general-purpose score proprietary models used to predict credit risk. The Equifax Credit Score uses numerical range of 280 to 850 , where higher scores indicate lower credit risk. The FICO score also uses a numerical range of 300 to 850 , where higher scores also indicate lower credit risk. The New York FED's Consumer Credit Panel is based on a nationally representative sample drawn from anonymised Equity credit data.
} 
affluent customers. But on top of that, these favourable conditions are very sensible to the monetary policy. Once the FED will stop the quantitative easing policy, as it is already announced, interest rates will increase and car financing will tighten.

\section{Conditions of long-term growth are still not there.}

To summarise, the cyclical factors analysed above, job creation, deleveraging, pent-up demand, quantitative monetary easing will fuel automobile demand for the near future but cannot sustain a new growth cycle on the long-term. The decisive factor will be job creation and income. In this regard, perspectives are bleak. Although employment has returned to its pre-recession level, job creations have not been strong enough to offset job losses accumulated during the "Great Recession" and full employment is still very far off. To create enough jobs, the economy should grow for a sustained period at a pace above its long-term trend so that the gap between aggregate demand and the productive potential can be filled (Josh 2014). Due to joblessness, growth has been sluggish so far because household demand, with the exception of automobile, has remained subdued. Officially, the unemployment rate has fallen to $6.3 \%$ percent in April 2014, below the level of November 2008 when Barack Obama was first elected president but still above the rate of $4.3 \%$ before the crisis in 2007 . Worse, this improvement in unemployment hides the fact that the participation rate, the share of adult population deemed available for work, is falling. To be classified as unemployed, adults must identify themselves as actively seeking work. Due to the scarcity of jobs during the "Great Recession", many adults have abandoned active search. but would return to active work if job opportunities were numerous. The number of these "missing workers" increased to an all-time high of 6.2 million (Shierholz 2014). "If those missing workers were in the labour force looking for work, the unemployment rate would be 9.9 percent instead of 6.3 percent" (Shierholz, op cit). Meanwhile, these "missing workers" weigh down on wages. Wages have seen no growth since December 2009 and are stagnant around $2 \%$ in nominal terms and around $1 \%$ in real terms. This explains the weakness of demand and why the recovery is much slower than previous ones.

As we have seen in Figure 2, the gap between real compensation and labour productivity is still very large because real compensation gains were close to zero over the period 2008-2013. The labour income share continued to decline and inequalities to grow. Thanks to the profound deleverage that occurred between 2008 and 2013 it seems that everything is again in place for the same story to happen again but not in the same favourable circumstances as in the nineties. Households are taking new debt again but, in a context, where after five years of fall, the real median income in 2012 with USD 51,000 has returned to its 1995 level (see Figure $6)$. 
The bleak labour market does not signal a fast improvement. Over indebtedness will come sooner than in the previous growth cycle because in 2012 total consumer debt still amounted to $102 \%$ of households' disposable income. This is much better than the $125 \%$ of 2007 at the eve of the recession but still a high starting point for a new cycle of indebtedness. As regard income inequality, they are as high as ever with a Gini coefficient of 0.477 in 2012 up from 0.397 in 1975 which places the USA on the higher end of inequality among rich countries (see Figure 6). The lesson is clear: when the positive effect of the short-term factors analysed above will wane, households' debt will take over and will fuel the growth of the automobile market for some more years. And when the wedge between stagnant real income and growing debt will be too wide, a new recession will occur. In the meantime, the demand for automobile will have to cope with some structural problems.

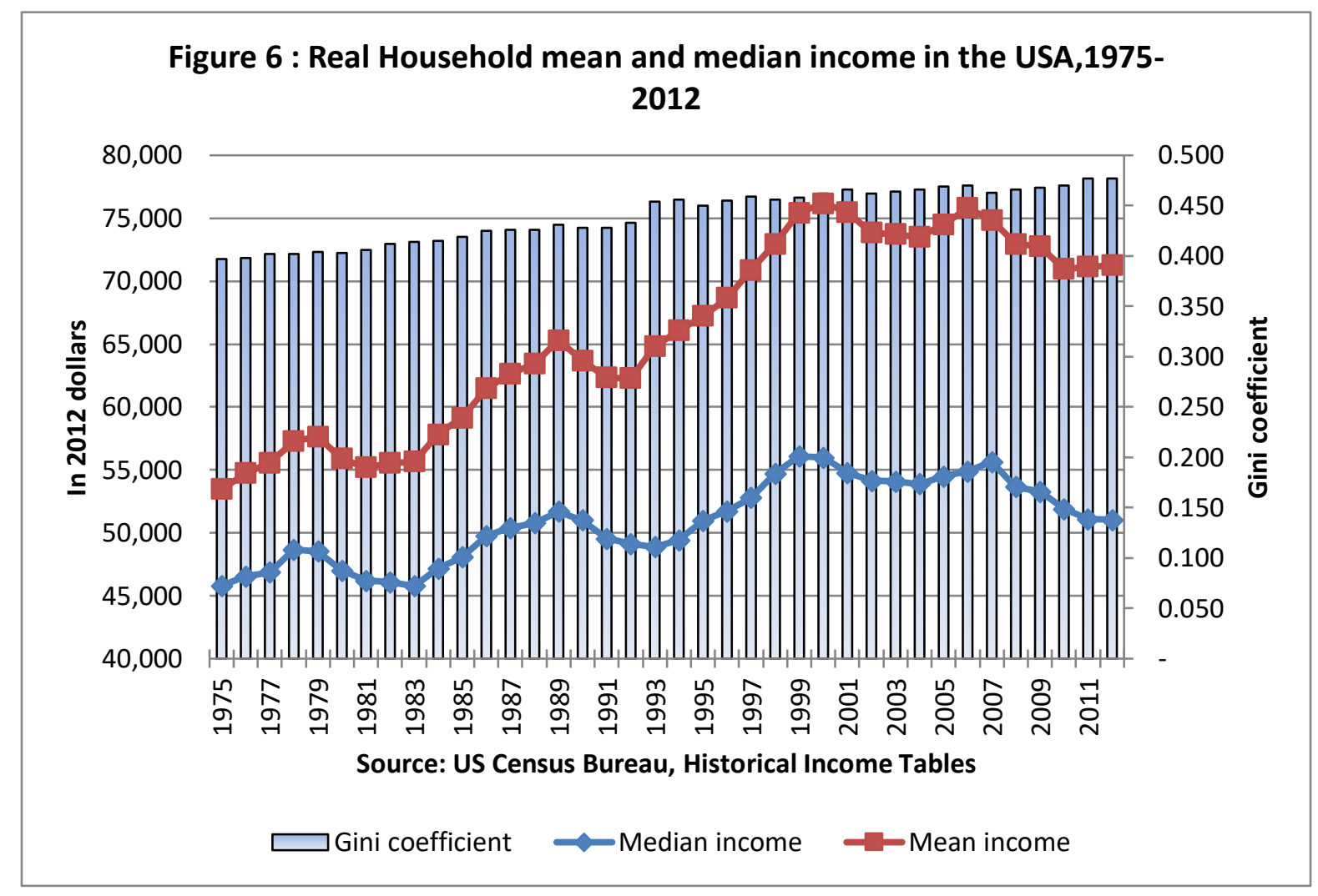

\section{Structural problems are still hampering automobile demand.}

Historically, the rapid fall of car price has been critical for the transformation of the automobile into a mass market. "Fordism" has been the technological, organisational and institutional breakthrough at the micro and macro level that enabled the transformation of cars from a luxury to a mass product (Boyer and Freyssenet 2002). One century after the invention of "Fordism", one may wonder if new cars are still affordable to the majority of consumers. In constant dollars, the price of a new car was USD 25,233 in 2011, which places it between the price of 1915 and 1916 (see 
Figure 7). Of course, the car of the $21^{\text {st }}$ century offers much more value for money than one century ago. Still the question of affordability of new cars remains. The analysis of the purchase of new vehicles by income quintiles shows that all households except the highest quintile had started to reduce their spending on new vehicles in 2003, four years before the "Great Recession, because their income had not fully recovered from the previous recession. The highest quintile was the only one to increase its annual spending in 2005 and 2006 to around US $\$ 4,800$ before it plummeted after the "Great Recession" to US\$ 2,800 in 2010 (see Figure 8). The highest quintile is also the only one for which spending on new vehicles is always superior to used vehicles. On average over the period $1984-2012$, the $20 \%$ richest spent 1.7 times more on new vehicles than on used vehicles. At the other extreme, the $20 \%$ poorest spent 1.6 times more on used vehicles than on new vehicles over the same period. The intermediary quintiles, which include the middle class, spent more money on new vehicles than the lowest quintile. Still, they spend more money on used vehicles than on new vehicles.

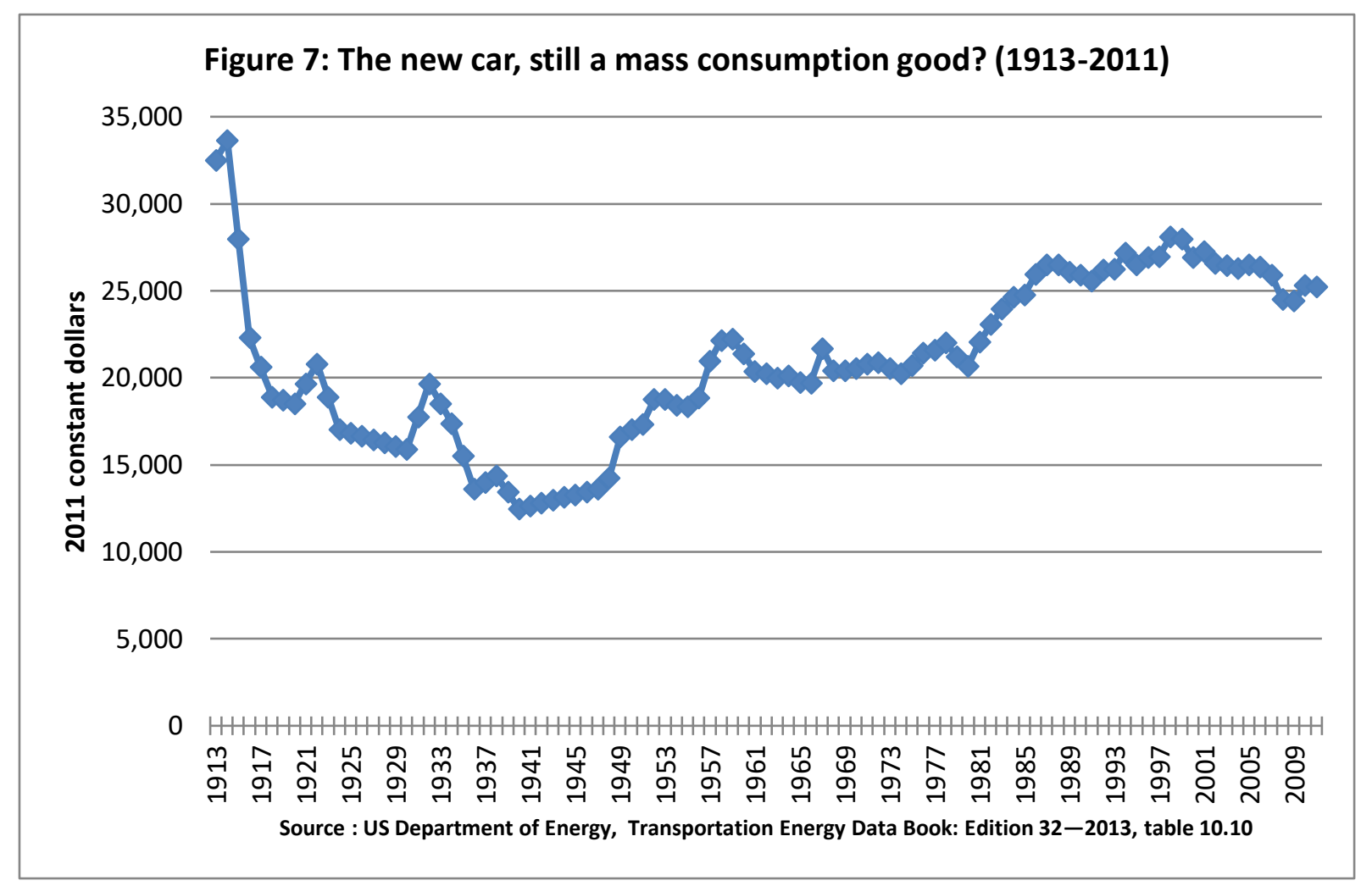




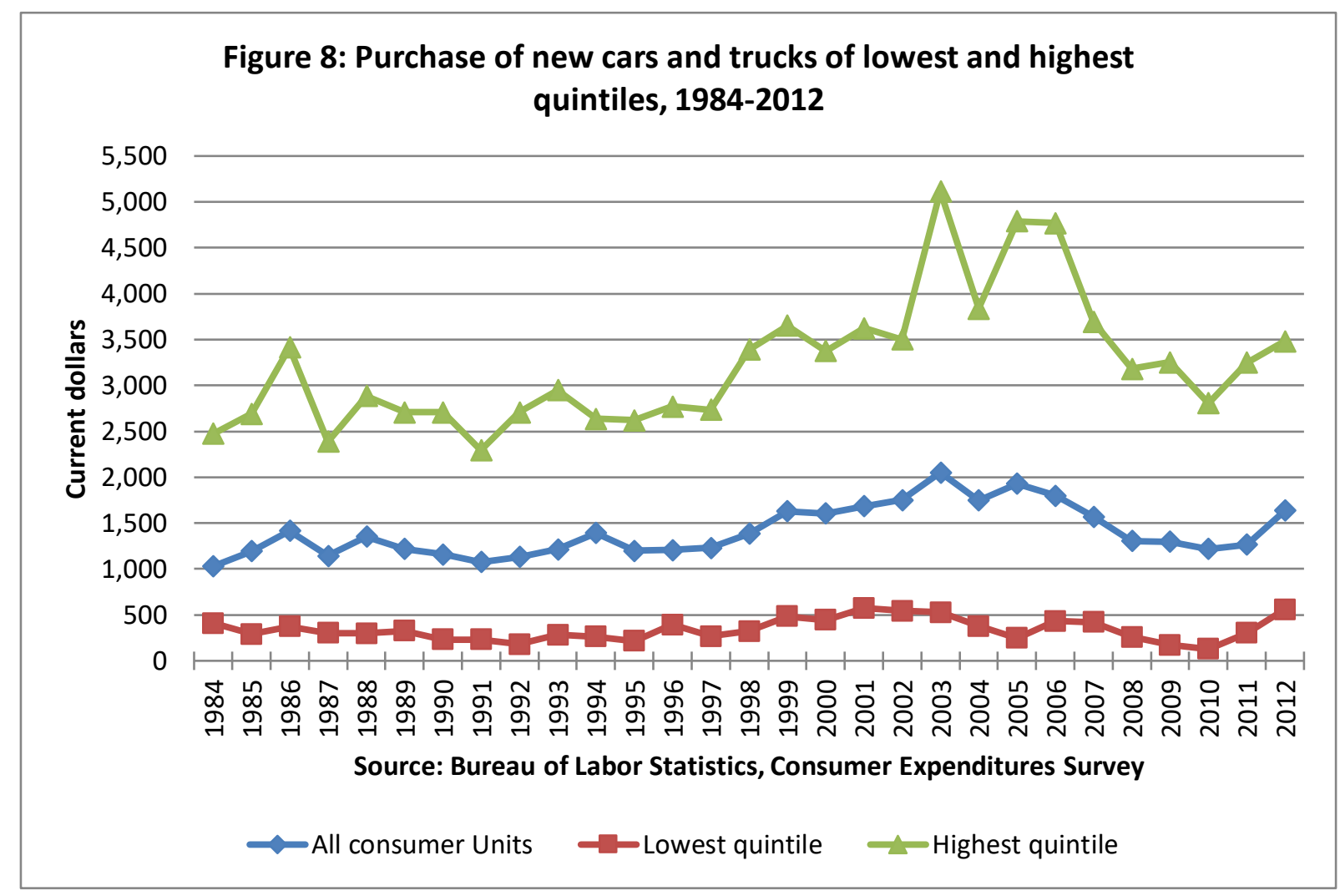

Another effect of growing inequalities on consumption is the bias it has introduced in favour of ever-bigger goods. This phenomenon has been detected in housing (Dwyer 2009) and automobile(Knittel 2009), (Bhat et al. 2009), (Choo and Moktharian 2004). This can be seen in the size of the vehicles purchased (see Figure 9) and in particular with the progression of big size pick-up trucks and SUVs. 


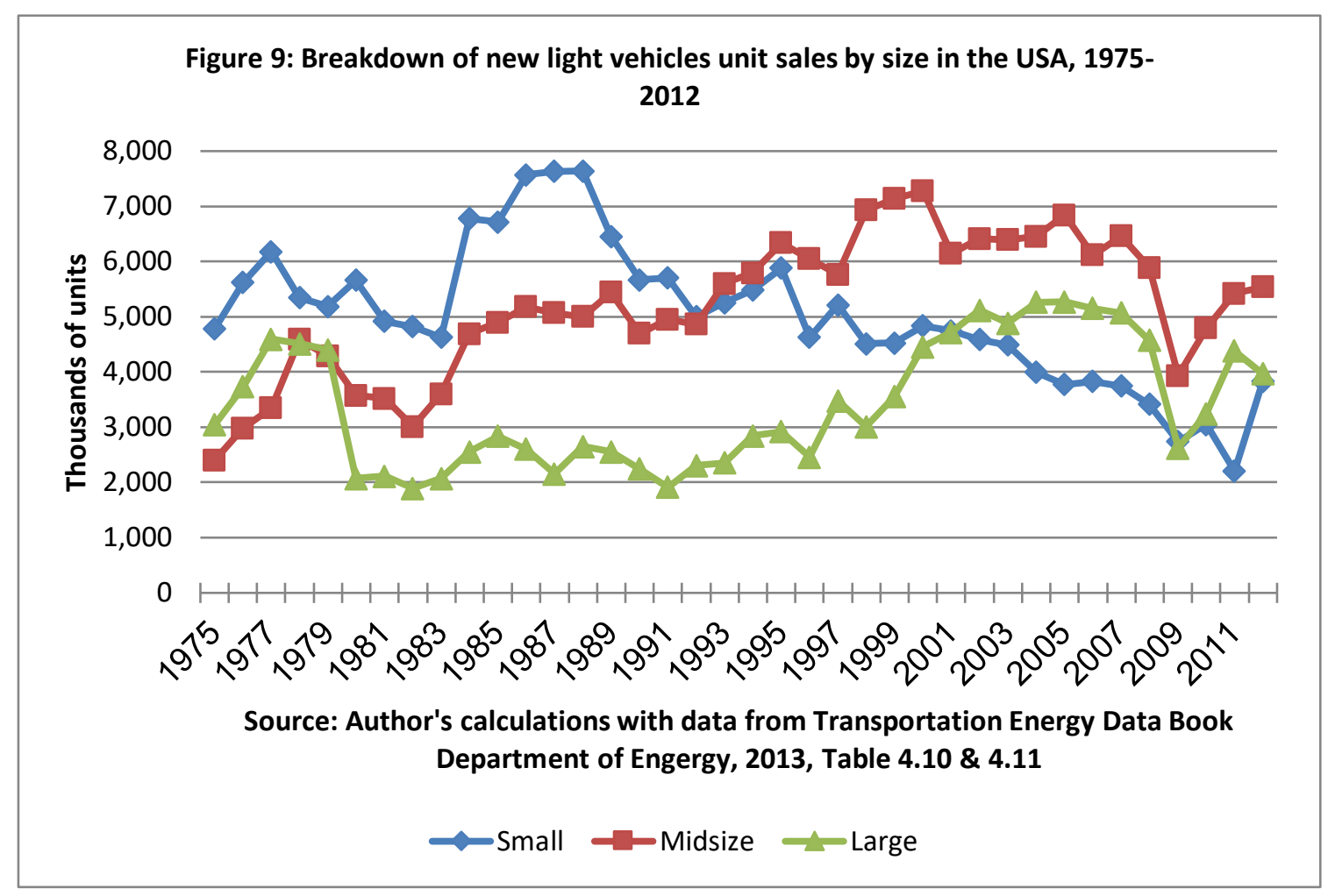

Small size vehicles were the major segment of the new vehicle market in the seventies and eighties. Then in the nineties the midsize segment became the top one. This marks the progress of the middle class during the long period of growth at the time of the "new economy". During the "jobless" recovery of the years 20012007 the housing bubble powered by subprime mortgage loans was compounded by an automobile bubble whereby new auto sales were financed by subprime auto loans. At that time, large vehicles sales with an average of 5.068 million units $^{13}$ exceed small vehicles ones (4.167 million units) that are the primary choice of low wage earners who are the most affected by the sluggish recovery. Obviously something is wrong because rich people are much less numerous than low wage-earners and a mass market can only be sustainable if established on much sounder base. During the year 2009, the worst of the "Great Recession", large vehicles sold almost as much as small vehicles, 2.6 versus 2.7 million. This reflects the influence of the top richest quintile of households who has a strong preference for these large vehicles. These rich Americans were less affected by the crisis. In fact, their income recovered rapidly and even progressed after 2009. They maintained their purchase of large and luxury vehicles, a phenomenon which was also observed for other luxury goods.

\footnotetext{
${ }^{13}$ Author's calculation with data from Transportation Energy data book 2013, Department of Energy, table 4.10 and 4.11. We have added all categories of vehicles, cars, van, non-truck SUVs, pick-up trucks, truckSUVs by size: small, midsize and large.
} 
Because large vehicles are expensive, a minority of affluent customers buy them new and a majority buy them on the used vehicle market. The used vehicle market is by far the biggest automobile market. On average, over the period 1990-2013, it sold 2.7 more vehicles than the new vehicle market ${ }^{14}$. During the period of crisis, more customers buy used vehicles to save money and the ratio exceeds three used vehicles for a new one. In other terms, the new vehicle market represents on average $27 \%$ of total used and new vehicle sales of around 55 million unit sales on the period 1990-2013. For vehicle wholesalers and retailers, the used market is much more profitable than the new market. Firstly, because in period of crises the strong demand of recent used vehicles makes their prices soar. Secondly, because owners hold on longer their vehicles which increase repair and maintenance cost.

The automobile market including both new and used light vehicles reach an alltime record in 2006 with a total value of USD billion 786 and then decline during the "Great Recession" to USD billion 575 in $2009^{15}$. Once the market will have fully recovered, one wonder whether there is still a potential for future growth. Two issues raise questions about the market potential: the shift of consumer demand in favour of services and away of traditional consumer goods like the automobile and the evolution of demographics.

Over the period 1929-1940, services accounted for $45 \%$ of households expenditures ${ }^{16}$. During the post-war "Fordist" growth, their share increased a little up to $47.5 \%$. But over the last period (1980-2012), they jumped to $62.5 \%$ of households' expenditures (see Figure 10). Much of this progress was at the expense of nondurable goods. Their share over the period 1980-2012 amounts on average to $24.8 \%$ down from $45 \%$ before the war. The share of durable goods, among them automobile, registered only a small decline: $12.7 \%$ in the years $1980-2012$, down from $14.6 \%$ in the years $1949-79$. But a closer look at some big-ticket items shows that the decline in automobile spending is more pronounced than one may expect.

\footnotetext{
${ }^{14}$ Source: Authors' calculation with data from, National Transportation Statistics, Bureau of Transportation Statistics, table 1-17, updated 2013.

15 This including leases. Source: Authors' calculation with data from, National Transportation Statistics, Bureau of Transportation Statistics, table 1-17, updated 2013.

${ }^{16}$ All the data presented in this part come from the national accounts published by the Bureau of Economic Analysis and in particular table 2.4.5 which presents personal consumption expenditures.
} 


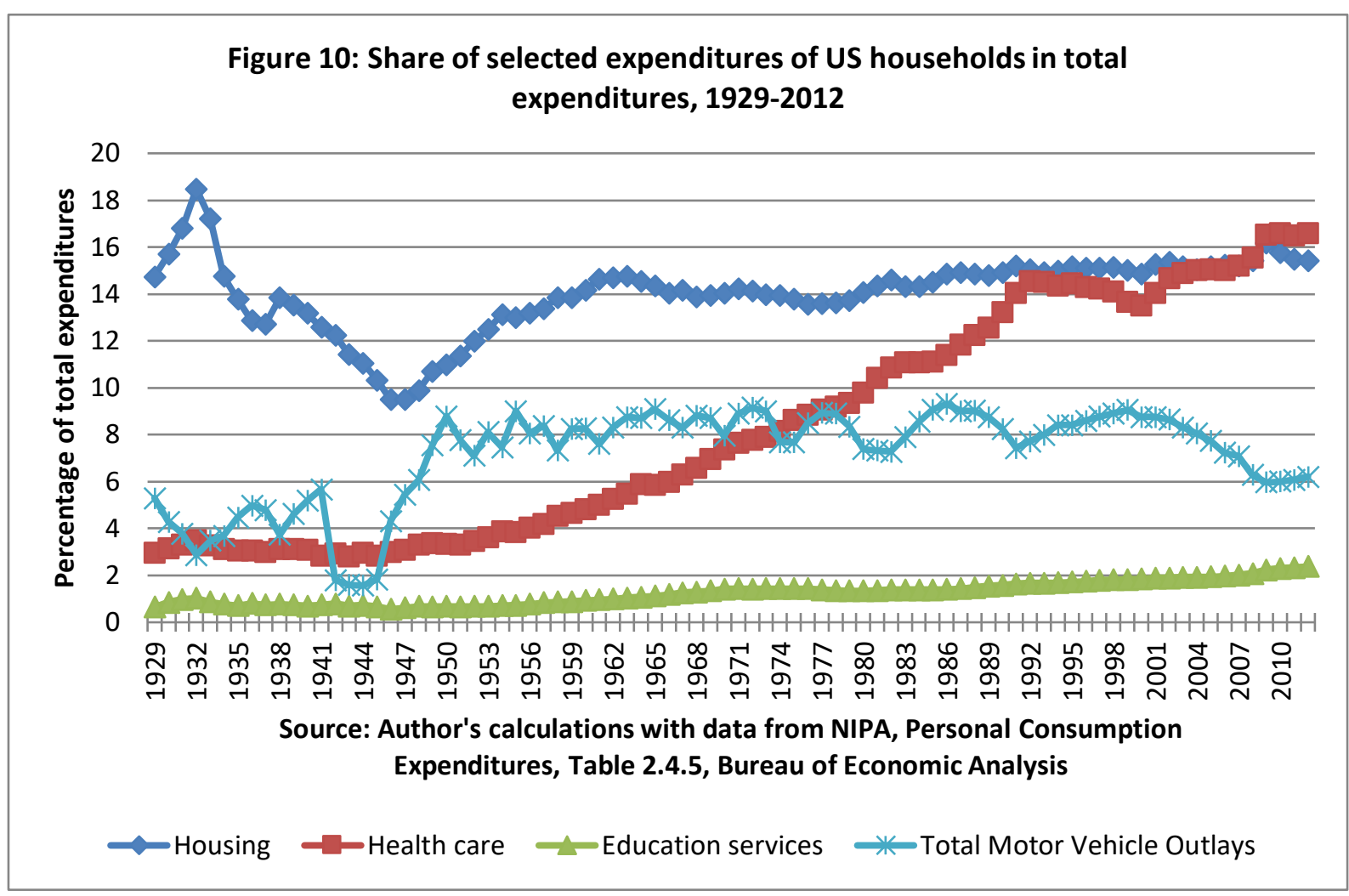

The share of total vehicle outlays peaked in 1999 towards the end of the longest growth cycle of the post-war era (1991-2000) but then declined steadily long before the "Great Recession". They were down to 6\% in 2007 where they still are in 2012. Housing has traditionally been the biggest item and after the Second World War increased gradually from $14 \%$ of total households' expenditures to $16 \%$ in 2009 . But what is impressive is the sharp growth of health care spending which became the biggest item with more than $16 \%$. It reflects the fact that the US health system is one of the most expensive and inefficient of rich countries which now limits the spending that households could dedicate to other items such as automobile. To a lesser extent, spending on education services has also increased regularly and now accounts to over $2 \%$ of households' expenditures, two times the level of the sixties. Higher education expenses are mainly responsible for this increase. Communication services, and among them mobile phone and internet access also account for about $2 \%$ of households expense. While looking small, these expenses also compete with the consumption of durable goods.

A detailed breakdown of automobile spending reveals other interesting facts (see Figure 11). While the share of total motor vehicle outlays has remained stable until 2001 , the share of new motor vehicles outlays has declined steadily from an average of $4.3 \%$ in the period $1949-79$ to $3.1 \%$ in the most recent period (1980-2012). Conversely, there is a significant increase in motor vehicle services (maintenance and repair and other services) from $1 \%$ in the thirties to almost $3 \%$ in the middle of the nineties and now $2 \%$. 


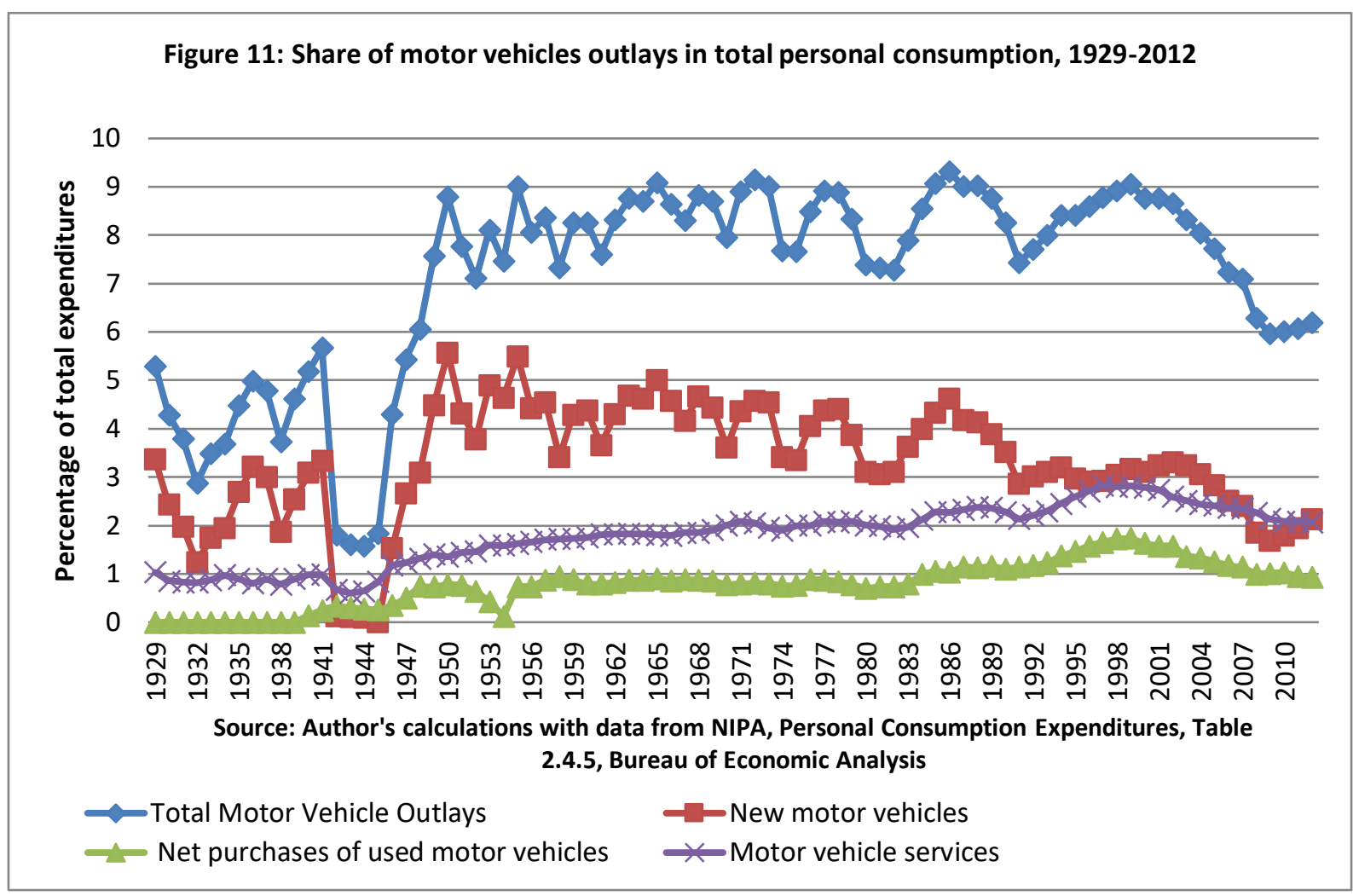

To a certain extent, this evolution is linked to the increasing complexity and technological content of vehicle, and the high profit margin of parts and repair and maintenance services which makes the bulk of the profit of sales services ${ }^{17}$. Net used vehicles purchases had also almost doubled their share from $0.8 \%$ in the period $1949-79$ to $1.6 \%$ in the middle of the nineties when the majority of households bought a second vehicle, that one being usually a use vehicle. Finally, insurance costs add another $0.6 \%$ to households' spending. This item has been stable since the Second World War but is three times higher than in the thirties.

To summarise, expenditures on new vehicles are on a historical declining trend due to higher spending on other items linked to car ownership but also because of the higher price of critical spending like housing, health, education and communication. The share of new vehicle expenditures in total households' expenditures fell to an historical low level under $2 \%$ during the "Great recession" to be compared only with the "Great Depression" of the thirties. It will probably return to $3 \%$ in a near future but it is doubtful that it will recover its historically high average of $4.3 \%$ registered during the "Golden Age" of post war growth.

Demography is another reason to believe that the US automobile market has entered a period of slow growth due to a relative saturation of the market. The

\footnotetext{
${ }^{17}$ For instance, in 2012 the net profit as percent of services and part sales amounted to $5.97 \%$ while total dealership net profit as percent of total sales was 2.2\%. Source: NADA Data Report 2013.
} 
percentage of households with no vehicle has dropped to 9.3\% in 2011 down from $21.5 \%$ in $1960^{18}$. It is probable that this percentage will not fall much further because this share of the population includes people who are too poor to buy a vehicle, or too old, or simply do not like automobiles and have other means of transport when they live in big cities ${ }^{19}$. Another reason is that households' vehicle ownership has already increased dramatically. In 1960, 78.4\% of households owned one vehicle. In 1990 it had declined to 45\% because most American women now work. But in 2011 the Figure was almost the same: $43.4 \%$. The third vehicle progresses but also at a declining pace because of financial constraint. In 1960, 97\% of households had less than 3 vehicles. By 1990, they were $82.6 \%$. By 2011, they were $80.9 \%$, a small improvement of $1.7 \%$ in 11 years. Since 1958 there are more vehicles in operation than civilian employed persons, which means that a second car is needed because both parents are working. But what is even more surprising is the fact that since 1986, there is more than one vehicle per licensed driver (see Figure 12). A significant number of drivers own more than one car either a new or a used one. This may be sustainable for a thriving economy but this is not precisely the case since the "Great Recession". Another concern for the future expansion of the automobile market is the fact that the percentage of license drivers in the total population is reaching a point of stagnation at $68 \%$ (see Figure 12). All these elements show that there may be still some room of manoeuvre for an extension of the automobile market, but they are getting scarce and not sufficient on the long-term.

\section{Financing vehicle sales with subprime loans.}

Without a huge finance industry there would not be a mass market for automobiles. Before the "Great Recession" about three quarters of new vehicles sales and half of used cars were financed either by loans or leases ${ }^{20}$. The dependence on the finance auto industry has increased to respectively $84 \%$ and $54 \%$ after the recession because households are less wealthy. The auto finance industry churns huge amount of money. In the fourth quarter of 2008 , when total debt balance for the whole USA registered an all-time record of 13 trillion dollars, automobile debt amounted to 800 billion dollars, i.e., $6.2 \%$ of the total, almost the same as credit card

\footnotetext{
18 This data and the following in this part come from various tables of "Transportation Energy Data Book, 2013, Department of Energy".

19 The 2009 National Household Travel Survey (NHTS) states that "almost thirty percent of the households in areas with a population density greater than 10,000 persons per square mile did not own a vehicle in 2009, a proportion that has remained steady since 1995" (NHTS, 2011, p 36).

${ }^{20}$ Source: The State of Automotive Finance Market, various editions, Experian.
} 
debt $(6.8 \%)$ and more than student loans $(5 \%)^{21}$. This is because vehicle purchase is the second largest purchase of households after the purchase of a home.

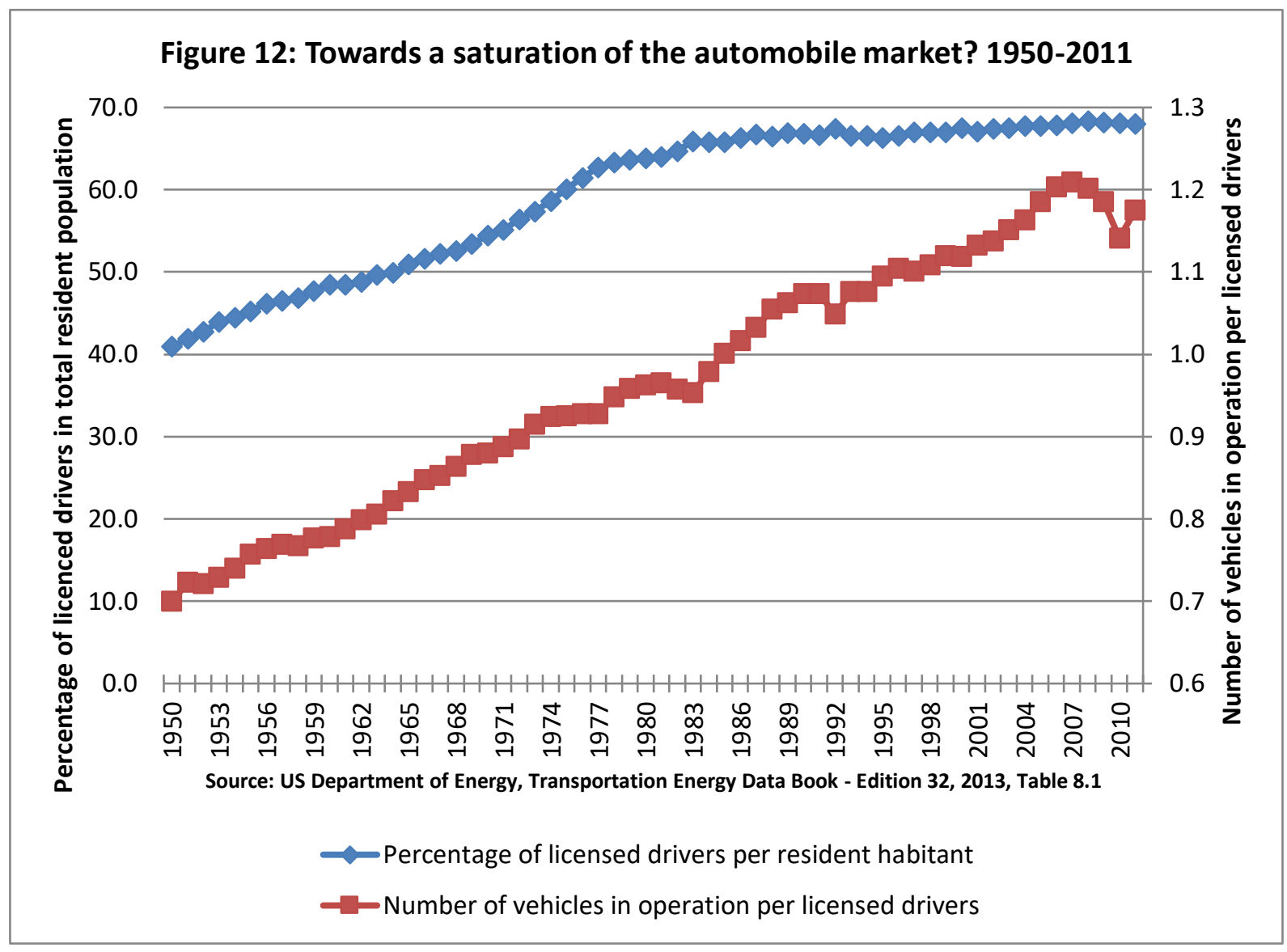

The auto finance industry is particular in the sense that auto makers usually own a financial subsidiary, called "captive auto finance" companies. This is not the case for other producers of consumer goods, but for auto makers it is crucial to be able to finance sales to "push" cars whatever the circumstances. Captive auto finance companies hold $30 \%$ of total on average during the period 2007-2013 in competition with banks (34\%), credit unions (22\%) and finance companies (14\%) (Source: Experian). They assess customers with credit scores the most famous being the FICO scores but many companies have their own proprietary risk evaluation system. It is the same process as for buying a home. Car buyers are divided in risk categories according to their income, job, households' characteristics, and past financial record (being late on debt payment or worse bankruptcy). Experian for instance ranks customers from top to bottom into Super-prime, prime, non-prime, subprime and deep subprime risks. The riskier the customer is, the tightest the conditions of the loan: higher interest rate, higher monthly payment, smaller amount financed. Auto finance agents have different strategies: usually banks, credit unions and captive

\footnotetext{
${ }^{21}$ The vast majority being house mortgage with $73 \%$ of total households' debt at the time. Source: FED of New York, HHD C Report, various issues.
} 
companies compete for the best customers while auto finance companies focus on non- prime, subprime and deep subprime customers because these companies accept more risk to make more profit. But all of them have a diversified portfolio whose exact composition varies according to their strategy. Before the "Great Recession", the bad risks (below prime) market share amounted to around $38 \%^{22}$ (see Figure 13).

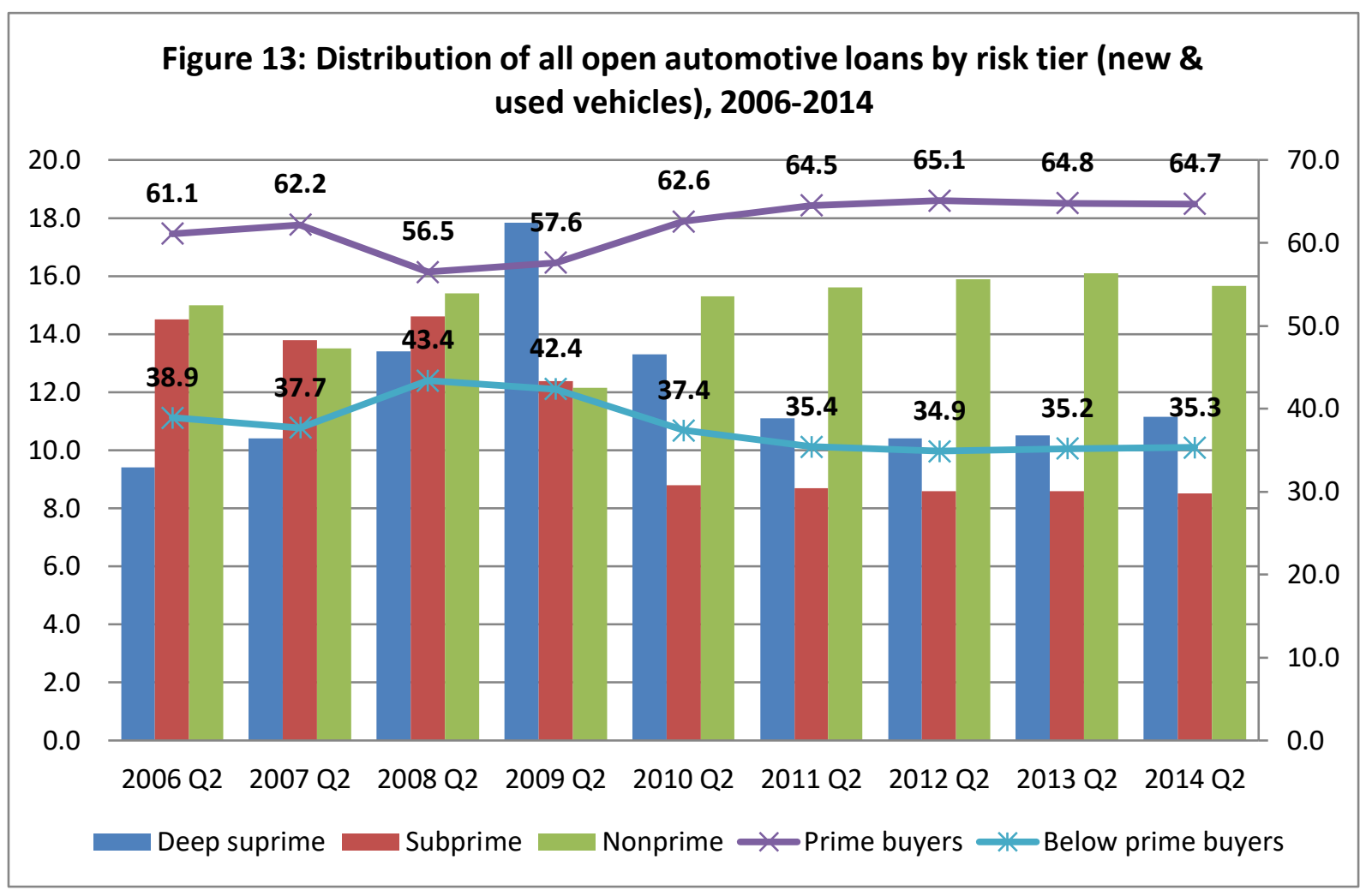

It means that $38 \%$ of vehicle customers were already in difficult situation when buying a car. With the recession, this share raised to $43.4 \%$ in 2008 . The share of deep subprime borrowers recorded an all-time high of around $18 \%$ of the market in the second quarter of 2009. Lenders tightened their lending criteria to filter belowprime borrowers out of the market. With numerous charge-offs of delinquent loans, the auto finance market improved its risk profile. Since 2011, the share of below prime loans amounts to $35 \%$ which is low by historical standards, while prime loans forms the bulk of the market with the remaining $65 \%$. While this situation may seem healthy on a risk assessment point of view, it is bad news for car makers and lenders because it means few buyers. This is why once the economy started to improve and households had cleaned their balance sheet, lenders rushed to make new auto loans even to subprime and deep subprime borrowers. The reason is to be found in the state of financial markets. Because of the quantitative monetary easing, financial

\footnotetext{
22 Below-prime is the sum of deep subprime, subprime and non-prime risks. The following development rests on Experian data unless specified.
} 
returns are very low and many finance companies are willing to take risks to boost their profit. Many invested in the auto finance market and in particular the auto assetbacked security market. This market had almost closed during the "Great Recession" and reopened in 2011. It is very important for loans to below prime customers. Like for the subprime home market before the recession, auto lenders sell part of their auto loans on secondary markets, called asset-backed security market, once loans have been transformed into securities. With this process, auto lenders get rid of the risk attached to below prime borrowers as it is bought by investors willing to take this risk for a profit. This system worked well before the "Great Recession" until it provoked the famous "subprime crisis". Of course, the situation is now different because households have deleveraged a lot and lenders have a lot of money to lend. But the same cause will lead to the same consequences especially because the recovery is not backed by a buoyant labour market and households' income is still low. One can assess the return of future trouble with Figure 14 which focuses on the relation between auto loan delinquency and new auto loans.

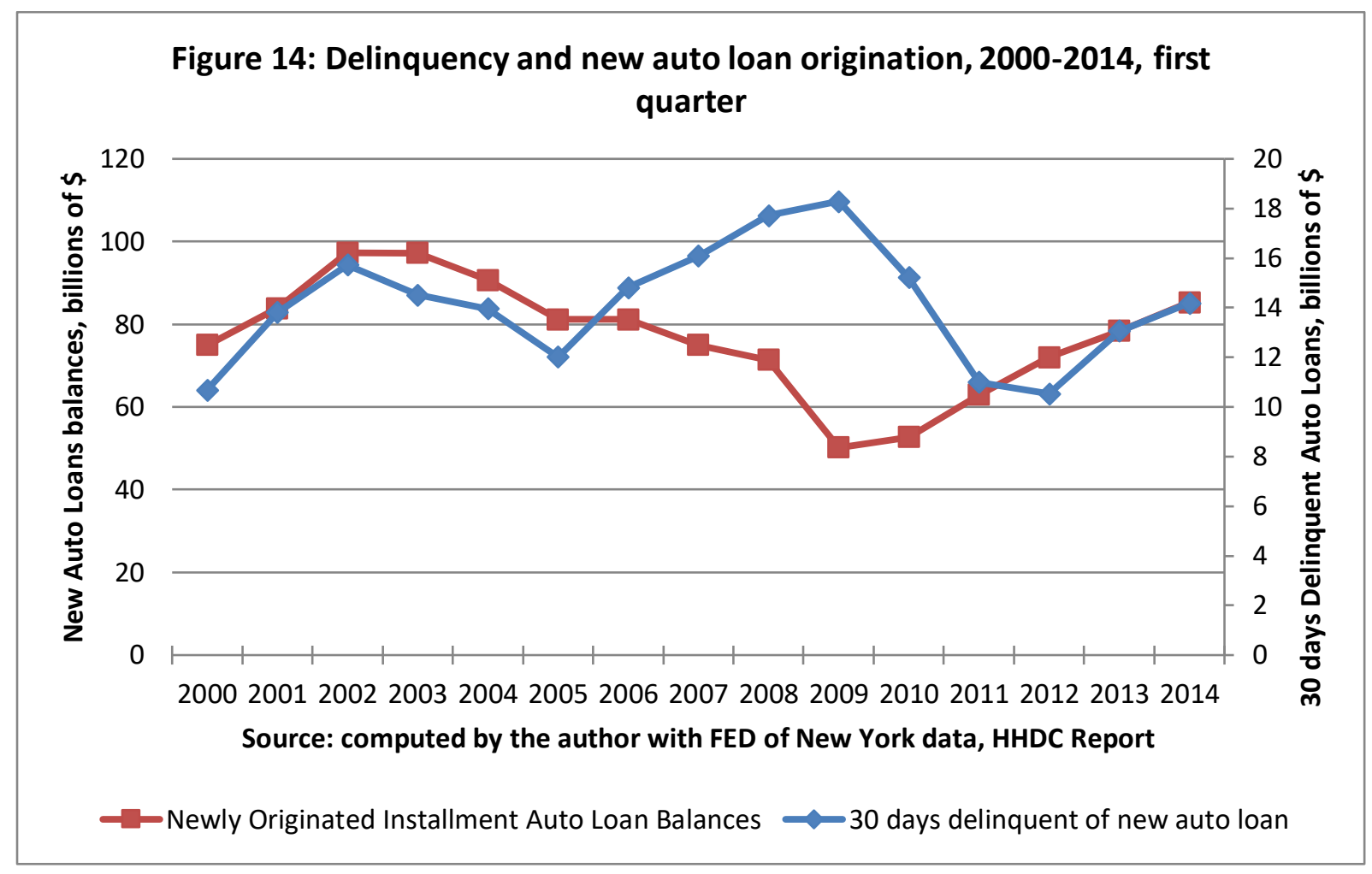

Three different phases can be distinguished. Between the years 2000-2005 marked by the dot.com bubble burst and the recession that follows, new auto loans and auto loan delinquency go up and down together which is a normal pattern. When the volume of loans increases, it incorporates more borrowers with a lower credit score such as subprime borrowers and vice-versa. Over the period 2005-2012, one observes an opposite relationship between new auto loan and delinquency. Delinquency soars while auto loan origination plummets, the apex being reached during the worst of the recession in 2009. This reflects the working of the crisis. Many 
vehicle owners cannot pay back their auto loans and auto lenders are restricting their loans to prime and super prime customers. When the economy starts to recover in 2010, the relationship is still opposite but reflects the best situation possible for auto lenders: they can increase again their loans while auto loans delinquency falls. The third period starts in 2013 and resume with the normal pattern. The extension of the auto loan market to poorer and riskier customers, those who are deemed deep subprime and subprime borrowers induce an increase in auto loan delinquency. In fact over the years 2013 and 2014, one observes a rush of equity funds in search of the big speculative gains that subprime and deep subprime customers provide because they pay a high interest rate. Finance companies hold $15 \%$ of auto open loans in the second quarter of 2014 , but $34 \%$ of 30 days delinquent loans (up from $22.6 \%$ in the second quarter of 2009) and $45 \%$ of 60 days delinquent auto loans (up from $28 \%$ ). This concentration of risks is creating concern among the authorities.

This recent trend in automobile finance illustrates the contradiction auto makers and auto lenders are in: on the long run, they cannot lend to an ever increasing number of car buyers to increase car sales without taking more risks.

\section{Conclusion}

This chapter has examined the relationships between the US growth regime and the automobile market, the impact of the Great Recession and the factors which explain the recovery of the US automobile market. We have underlined the fact that cyclical and one-time positive factors are behind the strong recovery. These factors cannot last and the rebound of the US automobile market is not solidly grounded on long-term positive fundamentals. Actually, the deep causes of the "Great Recession" which are the gap between labour productivity and real income and very high inequality have not been addressed. As a consequence, households are getting indebted again. This is indeed the return to business as usual and not the birth of a new industry. 


\section{References}

Bhat, C. R., S. Sudeshna \& E. Naveen (2009) 'The impact of demographics, built environment attributes, vehicle characteristics, and gasoline prices on household vehicle holdings and use.', Transportation Research Part B, 43, 1-18

Bivens, J. \& I. John (2008) 'A Feeble recovery: the fondamental economic weaknesses of the 2001-2007 expansion.,' Economic Policy Institute Briefing paper 214

Boyer, R. \& M. Freyssenet (2002) The productive models: the conditions of profitability: Palgrave Macmillan)

Choo, S. \& P. L. Moktharian (2004) 'What type of vehicle do people drive? The role of attribute and lifestyle in influencing vehicle type choice.', Transportation Research Part A, 38, 201-22

Cooper, D. (2010) 'Did Easy Credit Lead to Overspending? Home Equity Borrowing and Household Behavior in the 2000s', Public Policy discussion Paper,

Dwyer, R. E. (2009) 'The McMansionization of America? Income stratification and the standard of living in housing, 1960-2000', Research in Social Stratification and Mobility, 27, 285-300

Haughwout, A., D. Lee, J. Scally \& W. Van der Klaauw (2013) 'Who is driving the auto lending recovery?', in Liberty Street Economics, (New York: Federal Reserve Bank of New York)

Josh, B. (2014) 'Nowhere CloseThe Long March from Here to Full Employment', in Report: Jobs and Unemployment (Washington, DC: Economic Policy Institute)

Knittel, C. R. (2009) 'Automobiles on steroids: Product attributes trade-offs and technological progress in the automobile sector, ' NBER Working Paper 15162

Lawrence, M., B. Jared \& S. Heidi (2008) The State of Working America 2008/2009: Cornell University Press)

Mian, A. \& A. Sufi (2009) 'House Prices Home Equity-Based Borrowing and the U.S. Households Leverage Crisis', Chicago Booth Research Paper 57

Mian, A. \& a. Sufi (2010) 'Household leverage and the Recession of 2007-09', IMF Economic Review, 58, 74-116

Pfirrmann-Powell, R. (2014) 'Americans' aging autos', Beyond the numbers, 3, 8

Ruben, M. (2009) 'Forgive us our Trespasses? The Rise of Consumer Debt in Modern America', in Discovery Guide: ProQuest)

Shierholz, H. (2014) 'Number of Missing Workers Jumps to All-Time High', in The Economic Policy Institute blog:

Stango, V. (1999) 'The Tax Reform Act of 1986 and the composition of Consumer Debt', National Tax Journal, 52, 717-39 